\title{
Review Article \\ Proinflammatory Cytokines and Potassium Channels in the Kidney
}

\author{
Kazuyoshi Nakamura, Hikaru Hayashi, and Manabu Kubokawa \\ Department of Physiology, Iwate Medical University School of Medicine, 2-1-1 Nishitokuta, Yahaba, Iwate 028-3694, Japan \\ Correspondence should be addressed to Manabu Kubokawa; mkubokaw@iwate-med.ac.jp
}

Received 24 July 2015; Accepted 9 September 2015

Academic Editor: Mauricio Retamal

Copyright ( 2015 Kazuyoshi Nakamura et al. This is an open access article distributed under the Creative Commons Attribution License, which permits unrestricted use, distribution, and reproduction in any medium, provided the original work is properly cited.

Proinflammatory cytokines affect several cell functions via receptor-mediated processes. In the kidney, functions of transporters and ion channels along the nephron are also affected by some cytokines. Among these, alteration of activity of potassium ion $\left(\mathrm{K}^{+}\right)$channels induces changes in transepithelial transport of solutes and water in the kidney, since $\mathrm{K}^{+}$channels in tubule cells are indispensable for formation of membrane potential which serves as a driving force for the transepithelial transport. Altered $\mathrm{K}^{+}$ channel activity may be involved in renal cell dysfunction during inflammation. Although little information was available regarding the effects of proinflammatory cytokines on renal $\mathrm{K}^{+}$channels, reports have emerged during the last decade. In human proximal tubule cells, interferon- $\gamma$ showed a time-dependent biphasic effect on a $40 \mathrm{pS} \mathrm{K} \mathrm{K}^{+}$channel, that is, delayed suppression and acute stimulation, and interleukin- $1 \beta$ acutely suppressed the channel activity. Transforming growth factor- $\beta 1$ activated KCa3.1 $\mathrm{K}^{+}$channel in immortalized human proximal tubule cells, which would be involved in the pathogenesis of renal fibrosis. This review discusses the effects of proinflammatory cytokines on renal $\mathrm{K}^{+}$channels and the causal relationship between the cytokine-induced changes in $\mathrm{K}^{+}$channel activity and renal dysfunction.

\section{Introduction}

Renal tubular potassium $\left(\mathrm{K}^{+}\right)$channels are involved in a wide spectrum of the transepithelial transport in the kidney $[1,2]$. They contribute to the formation of the cell-negative potential, which serves as a driving force for the electrogenic passive transport of solutes, such as apical $\mathrm{Na}^{+}$entries through the $\mathrm{Na}^{+}$-glucose cotransporter (SGLT) in proximal tubule cells and the epithelial $\mathrm{Na}^{+}$channel $(\mathrm{ENaC})$ in the principal cells of cortical collecting duct (CCD) $[1,2]$. The apical $\mathrm{K}^{+}$ channels in the principal cells of CCD are the major pathway of $\mathrm{K}^{+}$secretion $[1,2]$. The renal tubular $\mathrm{K}^{+}$channels also play important roles in $\mathrm{K}^{+}$recycling for the apical $\mathrm{Na}^{+}-\mathrm{K}^{+}-2 \mathrm{Cl}^{-}$ cotransporter (NKCC) in the thick ascending limb (TAL) and the basolateral $\mathrm{Na}^{+}-\mathrm{K}^{+}$ATPase along the nephron $[1,2]$. In addition to the physiological importance, the renal tubular $\mathrm{K}^{+}$channels seem to be involved in the pathogenesis of renal cell injury or renal dysfunction. Some investigators reported that the blockade of $\mathrm{K}^{+}$channel activity ameliorated hypoxic renal cell injury [3-5]. Others reported that the decrease in
$\mathrm{K}^{+}$channel activity exacerbated renal ischemia/reperfusion injury $[6,7]$ or endotoxemic renal failure [8].

The cytokine family comprises a variety of multifunctional proteins, which play pivotal roles in immune modulation and inflammation $[9,10]$. Almost all organs are subjected to the modulatory effects of cytokines. The nervous system $[11,12]$, cardiovascular system [13], respiratory system [14], gastrointestinal tracts [15], and kidney [16] are also targets of cytokines. It is widely accepted that cytokines are secreted mainly by immune cells in response to microbial infection. However, other cell types are also capable of secreting cytokines $[9,10]$. The kidney proximal tubule cells produce proinflammatory cytokines in response to lipopolysaccharide (LPS) [17] or albumin [18]. It is thought that the proximal tubule cells function as the proinflammatory cells or immune responders, which play roles in the pathogenesis of renal dysfunction $[19,20]$. The TAL $[21,22]$ and collecting ducts [23] are also the sources of proinflammatory cytokines. Furthermore, renal tubule cells express specific receptors which mediate effects of individual cytokines [24-26]. 
Several proinflammatory cytokines, such as interferon- $\gamma$ $($ IFN- $\gamma$ ), interleukin-1 $\beta$ (IL-1 $\beta$ ), and tumor necrosis factor- $\alpha$ (TNF- $\alpha$ ), have been reported to affect $\mathrm{Na}^{+}$reabsorption in renal tubular epithelia [27-34]. Considering that the driving force of the transepithelial $\mathrm{Na}^{+}$reabsorption is dependent on the $\mathrm{K}^{+}$channel activity, as well as $\mathrm{Na}^{+}-\mathrm{K}^{+}$-ATPase $[1,2]$, it is important to know whether cytokines would affect the $\mathrm{K}^{+}$channels. These proinflammatory cytokines were also reported to cause cell injury in various organs, including the kidney. Since the alterations in $\mathrm{K}^{+}$channel activity were involved in renal cell injury as described above, it is possible that the cytotoxic effects of proinflammatory cytokines would partly be mediated by their action on renal $\mathrm{K}^{+}$channels. To date, however, information is restricted, regarding the effects of cytokines on $\mathrm{K}^{+}$channel activity in renal tubule epithelia. This is in sharp contrast to the accumulating evidence for the effects of cytokines on neuronal ion channels [35]. In this review, we discuss the effects of proinflammatory cytokines on renal tubular $\mathrm{K}^{+}$channels and the relevance of such effects to renal cell damage.

\section{Effects of Cytokines on $\mathrm{K}^{+}$Channels in the Proximal Tubule}

In the kidney, the proximal tubule reabsorbs about $70 \%$ of $\mathrm{Na}^{+}$filtered in glomeruli $[1,2]$. The basolateral $\mathrm{K}^{+}$channels provide the driving force for the apical $\mathrm{Na}^{+}$entry by forming the cell-negative potential and serving as the $\mathrm{K}^{+}$recycling pathway coupled with the $\mathrm{Na}^{+}-\mathrm{K}^{+}$-ATPase activity $[1,2]$. The effects of cytokines on the $\mathrm{K}^{+}$channels in human proximal tubule cells have recently been reported, using the patchclamp technique [36-38]. In cultured human proximal tubule cells (RPTECs) derived from the normal kidney, an inwardly rectifying $\mathrm{K}^{+}$channel with an inward conductance of $40 \mathrm{pS}$ is predominantly observed under the control condition [39]. Although the molecular characteristic of this $\mathrm{K}^{+}$channel is still unknown, electrophysiological studies revealed various functional properties. The $40 \mathrm{pS} \mathrm{K}^{+}$channel possesses a relatively high open probability ( 0.8 on average) with no voltage dependence [39] and contributes to the formation of cell-negative potential [40]. Furthermore, the activity of this $\mathrm{K}^{+}$channel is regulated by intracellular ATP [39], $\mathrm{pH}$ [39], and protein phosphorylation processes mediated by protein kinase A (PKA) [39] and protein kinase C (PKC) [38, 41], all of which are consistent with the properties of the basolateral $\mathrm{K}^{+}$channels in animal proximal tubule cells $[1,2,42]$.

It was reported that two proinflammatory cytokines, IFN$\gamma[36,37]$ and IL-1 $\beta[36,38]$, affected the activity of the $40 \mathrm{pS}$ $\mathrm{K}^{+}$channel in RPTECs. IFN- $\gamma$ possessed a time-dependent biphasic effect on the $40 \mathrm{pS} \mathrm{K}{ }^{+}$channel: a delayed suppressive effect and an acute stimulatory one [36, 37]. Both effects were blocked by inhibitors of Janus kinase (JAK) which was closely related to the IFN- $\gamma$ receptor, suggesting that the effects of IFN- $\gamma$ would be receptor specific [37]. In fact, human proximal tubule cells were reported to express IFN$\gamma$ receptors [24]. The delayed suppressive effect of IFN- $\gamma$ on channel activity was mediated, at least in part, by overproduction of NO in RPTECs [36, 37]. It was reported that NO stimulated activity of the $40 \mathrm{pS} \mathrm{K}^{+}$channel in RPTECs at

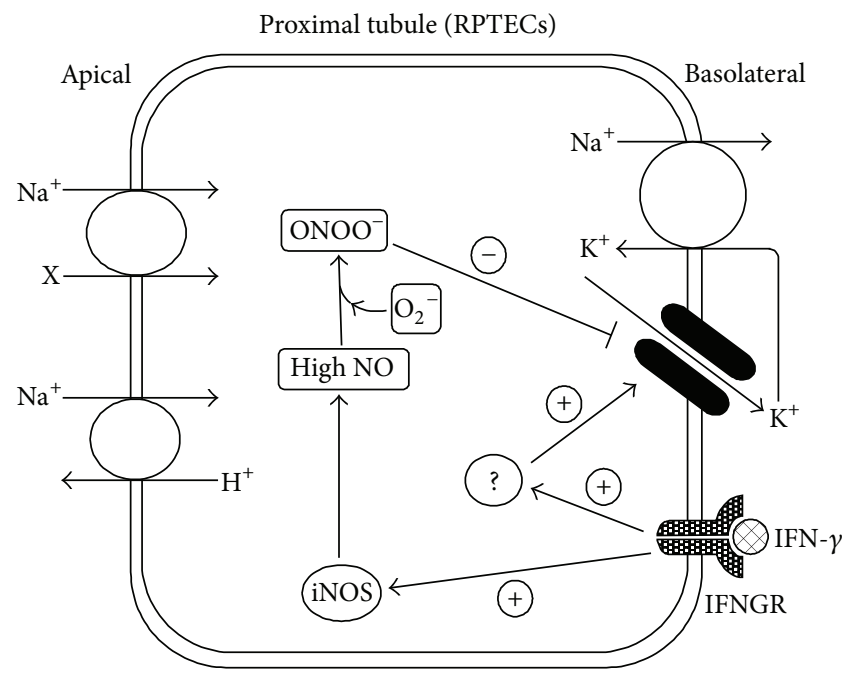

FIGURE 1: Illustration of the time-dependent biphasic effect of IFN$\gamma$ on the $40 \mathrm{pS} \mathrm{K}^{+}$channel in RPTECs. Prolonged treatment of cells with IFN- $\gamma$ greatly enhances iNOS expression, which results in generation of a large amount of NO. The excessive NO reacts with superoxide $\left(\mathrm{O}_{2}^{-}\right)$to form peroxynitrite $\left(\mathrm{ONOO}^{-}\right)$, which impairs the $40 \mathrm{pS} \mathrm{K}{ }^{+}$channel by oxidation and/or nitrosylation. IFN- $\gamma$ also acutely activates the $40 \mathrm{pS} \mathrm{K}^{+}$channel by unknown mechanisms. IFNGR: IFN- $\gamma$ receptor.

low concentrations (micromolar level) through activation of the cGMP/protein kinase G (PKG) pathway, whereas it suppressed channel activity at higher concentrations (millimolar level) [40]. The mechanism for the delayed suppressive effect of IFN- $\gamma$ is depicted in Figure 1. When RPTECs were treated with IFN- $\gamma$ for $24 \mathrm{~h}$, expression of inducible NO synthase (iNOS) was greatly enhanced, producing a large amount of NO. The excessive NO reacted with superoxide and generated peroxynitrite [37]. This peroxynitrite would suppress the $\mathrm{K}^{+}$ channel activity by oxidating or nitrosylating the channel and/or its related proteins $[37,40]$. Thus, the responses of the channels to NO modulators were reversed in IFN- $\gamma$-treated cells, compared to the control cells $[36,37]$. A NOS inhibitor, L-NAME, stimulated channel activity and a NO donor, Larginine, suppressed channel activity in IFN- $\gamma$-treated cells, whereas L-NAME suppressed channel activity and L-arginine stimulated channel activity in control cells [36, 37]. With regard to the acute stimulatory effect of IFN- $\gamma$, the mechanisms involved are currently obscure (Figure 1). Although the activity of the $40 \mathrm{pS} \mathrm{K}^{+}$channel was upregulated by PKA- and PKG-mediated phosphorylation processes $[39,43]$, inhibitors of these protein kinases failed to block the stimulatory effect of IFN- $\gamma$ [37]. Phosphatidylinositol-3-kinase (PI3 K) is one of the molecules that mediate the IFN- $\gamma$ signaling [44]. However, PI3 K inhibitors were also ineffective in blocking the IFN- $\gamma$-induced activation of the channel [37].

IL-1 $\beta$ also acutely affected the activity of the $40 \mathrm{pS} \mathrm{K}$ channel in RPTECs and the mode of action was suppressive $[36,38]$. The effect of IL-1 $\beta$ was highly likely receptor mediated, since the IL-1 receptor antagonist (IL-1RA) completely abolished it [38]. With regard to the existence of 


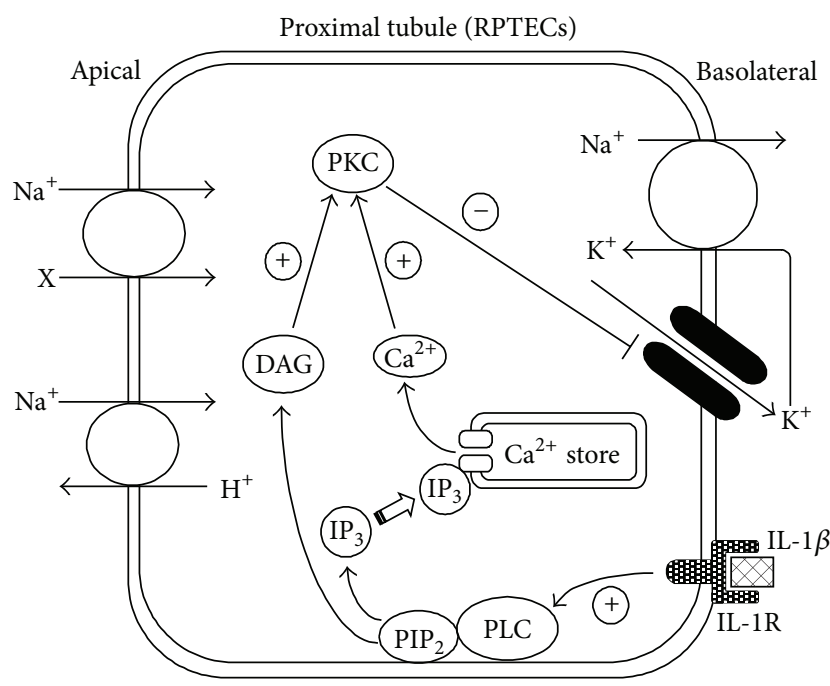

FIgURE 2: Illustration of the acute effect of IL-1 $\beta$ on the $40 \mathrm{pS} \mathrm{K}$ channel in RPTECs. IL- $1 \beta$ activates phospholipase C (PLC), which generates diacylglycerol (DAG) and 1,4,5-trisphosphate $\left(\mathrm{IP}_{3}\right)$ from phosphatidylinositol 4,5-bisphosphate $\left(\mathrm{PIP}_{2}\right)$ in the cytoplasmic membrane. Binding of $\mathrm{IP}_{3}$ to the $\mathrm{IP}_{3}$ receptor of the intracellular $\mathrm{Ca}^{2+}$ sore releases $\mathrm{Ca}^{2+}$. Both the DAG and increased intracellular $\mathrm{Ca}^{2+}$ activate $\mathrm{PKC}$, which consequently phosphorylates the channel and/or its related proteins, suppressing the channel activity. IL-1R: IL-1 receptor.

IL-1 receptors in the kidney, it was reported that the type I IL-1 receptors were widely distributed in renal tubules, as well as glomeruli [25]. In addition to IL-1RA, the acute suppressive effect of IL-1 $\beta$ was blocked by a PKC inhibitor and an inhibitor of phospholipase $C$ [38]. These observations strongly suggested that the effect of IL- $1 \beta$ was dependent on the PKC pathway (Figure 2). In support of this notion, PKC directly suppressed the activity of the $40 \mathrm{pS} \mathrm{K}^{+}$channel in inside-out patches [38], and fluorescent $\mathrm{Ca}^{2+}$ imaging using Fura 2 revealed that IL- $1 \beta$ increased intracellular $\mathrm{Ca}^{2+}[38]$, which was prerequisite for the activation of conventional PKC [45]. Furthermore, the PKC-dependent effects of IL$1 \beta$ were also observed in other ion channels, including the hippocampal $\mathrm{Ca}^{2+}$ channel [46], the middle ear $\mathrm{Na}^{+}$channel [47], the intestinal $\mathrm{Cl}^{-}$channel [48], and the $\mathrm{K}^{+}$channel in the cultured mouse CCD cell line, M1 cells (our unpublished observation). Although several investigators reported that IL$1 \beta$ increased iNOS expression in some tissues, such effect was not observed in RPTECs [36] or the nonpassaged primary culture of human proximal tubule cells [49]. Thus, IL-1 $\beta$ did not possess the NO-dependent delayed suppressive effect on the $40 \mathrm{pS} \mathrm{K} \mathrm{K}^{+}$channel, which was demonstrated by IFN $-\gamma$.

Huang et al. [50] have recently reported that transforming growth factor- $\beta 1$ (TGF- $\beta 1$ ) upregulated the KCa3.1 channel in immortalized human proximal tubule cells, HK2. According to their report, the whole-cell current sensitive to TRAM34, an inhibitor of KCa3.1, was profoundly increased after treatment of HK2 cells with TGF- $\beta 1$ for $48 \mathrm{~h}$, while the TRAM34-sensitive current was not observed in control cells. The mRNA expression of KCa3.1 was also increased by TGF- $\beta 1$. KCa3.1 is an intermediate conductance $\mathrm{Ca}^{2+}$ activated $\mathrm{K}^{+}$channel and widely distributed throughout the body, excepting most of excitable tissues [51]. Much more attention has been paid to this $\mathrm{Ca}^{2+}$-activated $\mathrm{K}^{+}$channel because of its pathological relevance in various diseases, including asthma, atherosclerosis, autoimmunity, and renal fibrosis [51]. Indeed, Huang et al. [50] suggested that the activation of KCa3.1 would play an important role in the TGF$\beta$-induced renal fibrosis. TGF- $\beta$ increased KCa3.1 activity, which in turn contributed to the activation of mitogenactivated protein kinase signaling and increased expression of monocyte chemoattractant protein-1 [50].

\section{Effects of Cytokines on $\mathrm{K}^{+}$Channels in the TAL and CCD}

The first report that cytokines affect $\mathrm{K}^{+}$channel activity was presented in 2003 by Wei et al. [52], who clearly demonstrated that TNF acutely stimulated activity of a $70 \mathrm{pS} \mathrm{K}^{+}$channel in the apical membrane of rat TAL, using the patch-clamp technique. Although the PKA- and nitric oxide- (NO-) dependent pathways had been shown to stimulate the activity of the $70 \mathrm{pS} \mathrm{K} \mathrm{K}^{+}$channel $[53,54]$, both a PKA inhibitor and an inhibitor of NO synthase did not affect the TNF-induced activation of the channel [52]. In contrast, an inhibitor of protein tyrosine phosphatase (PTP) blocked the stimulatory effect of TNF on channel activity [52]. Furthermore, an inhibitor of protein tyrosine kinase (PTK) increased channel activity, and the subsequent administration of TNF in the presence of the PTK inhibitor did not cause additional increase in channel activity [52]. It was also demonstrated that TNF significantly increased the PTP activity in cultured rat TAL cells [52]. Therefore, they concluded that the stimulatory effect of TNF on the $70 \mathrm{pS} \mathrm{K}^{+}$channel was dependent on tyrosine dephosphorylation processes mediated by PTP [52], as shown in Figure 3.

It is well known that a ROMK-like $30 \mathrm{pS} \mathrm{K}^{+}$channel, as well as the $70 \mathrm{pS} \mathrm{K}^{+}$channel, is present in the apical membrane of TAL $[52,53]$. Both $\mathrm{K}^{+}$channels contribute to the $\mathrm{K}^{+}$recycling across the apical membrane of the TAL, which maintains the normal function of the NKCC $[1,2]$. Wei et al. [52] also found that TNF did not affect the activity of this $30 \mathrm{pS} \mathrm{K}{ }^{+}$channel.

With regard to ROMK, there are also reports demonstrating that the gene expression of this $\mathrm{K}^{+}$channel was modulated by cytokines [32]. Schmidt et al. [32] reported that administration of proinflammatory cytokines, such as IL- $1 \beta$, IFN- $\gamma$, and TNF- $\alpha$, to the mouse decreased mRNA expression of ROMK in the whole kidney. Although the systemic administration of cytokines resulted in hypotension and reduced blood flow in the kidney, renal ischemia itself had no apparent effect on ROMK gene expression [32]. In addition, IL- $1 \beta$, IFN- $\gamma$, and TNF- $\alpha$ suppressed ROMK gene expression in the mouse CCD cell line to the same extent observed in the whole animal experiments [32]. Therefore, they strongly suggested that the proinflammatory cytokines directly suppressed the ROMK gene expression [32]. 


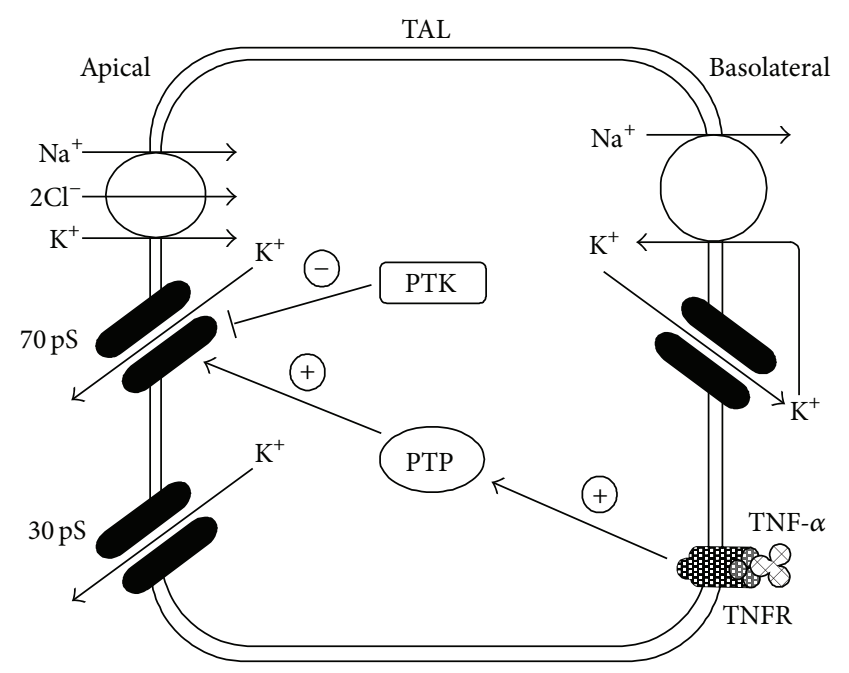

FIgURE 3: Illustration of the acute effect of TNF- $\alpha$ on the $70 \mathrm{pS} \mathrm{K}{ }^{+}$ channel in the TAL. TNF- $\alpha$ stimulates PTP activity, which causes tyrosine dephosphorylation of the $70 \mathrm{pS} \mathrm{K}^{+}$channel and activates it. TNFR: TNF receptor.

\section{Cytokine-Induced Changes in Activities of $\mathrm{K}^{+}$Channels and Transporters in the Kidney}

The activities of renal tubular $\mathrm{K}^{+}$channels are functionally coupled to various transporters $[1,2]$. Basolateral $\mathrm{K}^{+}$channels in proximal tubule cells cooperate with the basolateral $\mathrm{Na}^{+}$$\mathrm{K}^{+}$ATPase to provide a driving force for $\mathrm{Na}^{+}$entry through the apical transporters, such as SGLT $[1,2]$. Similar cooperation of basolateral $\mathrm{K}^{+}$channels with the $\mathrm{Na}^{+}-\mathrm{K}^{+}$ATPase also exists in distal nephron segments $[1,2]$. In the TAL, apical $\mathrm{K}^{+}$channels serve as the $\mathrm{K}^{+}$recycling pathways for the apical NKCC, which facilitates reabsorption of $\mathrm{Na}^{+}$and $\mathrm{Cl}^{-}[1,2]$. In principal cells of $\mathrm{CCD}$, apical $\mathrm{Na}^{+}$entry through the $\mathrm{ENaC}$ is partly dependent on the cell-negative potential generated by apical and basolateral $\mathrm{K}^{+}$channels $[1,2]$. Thus, the changes in renal $\mathrm{K}^{+}$channel activity would result in alterations in the transport activity of solutes and water. If the transport activity in the kidney drastically changes, the homeostasis of body fluid would be profoundly perturbed.

In contrast to the renal $\mathrm{K}^{+}$channels, there are relatively many reports demonstrating the effects of cytokines on renal transporters. TNF- $\alpha$ reduced ouabain-sensitive ${ }^{86} \mathrm{Rb}^{+}$uptake in the TAL [21] and NKCC expression in the kidney [31, 33]. These observations are inconsistent with the stimulatory effect of TNF- $\alpha$ on the $70 \mathrm{pS} \mathrm{K}{ }^{+}$channel in the TAL reported by Wei et al. [52]. The apical $70 \mathrm{pS} \mathrm{K}^{+}$channel acts as the recycling pathway for the apical NKCC $[1,2]$. Therefore, the TNF-induced increase in channel activity should be related to increased $\mathrm{Na}^{+}$transport. Such a discrepancy would partly be accounted for by the temporal factor. TNF- $\alpha$ reduced ${ }^{86} \mathrm{Rb}^{+}$uptake after $24 \mathrm{~h}$ [21] and NKCC expression after $4 \mathrm{~h}$ [31] or 7 days [33], whereas stimulation of channel activity by TNF- $\alpha$ occurred in a few minutes [52]. Besides the acute stimulatory effect on $\mathrm{K}^{+}$channel, TNF- $\alpha$ induces expression of cyclooxygenase (COX) which subsequently generates prostaglandin $\mathrm{E}_{2}\left(\mathrm{PGE}_{2}\right)$ [55]. It was reported that $\mathrm{PGE}_{2}$ suppressed the activity of the $70 \mathrm{pS} \mathrm{K}^{+}$channel in the TAL [56]. The effects of TNF- $\alpha$ on channel activity might be time-dependently biphasic similar to the effect of IFN- $\gamma$ on $\mathrm{K}^{+}$channel activity in RPTECs. If so, the delayed $\mathrm{COX} / \mathrm{PGE}_{2}$-dependent channel suppression would be consistent with the TNF- $\alpha$-induced inhibition of transport activity and transporter expression. TNF- $\alpha$ was also reported to increase SGLT2 expression in the porcine proximal tubule cell line, LLC-PK 1 [57], which well fits with the stimulatory effect of TNF- $\alpha$ on $\mathrm{K}^{+}$channel activity. IFN- $\gamma$ suppresses gene expression of various transporters. These include $\mathrm{Na}^{+}$$\mathrm{K}^{+}$ATPase [32, 58, 59], $\mathrm{Na}^{+}-\mathrm{H}^{+}$exchanger (NHE) [32], $\mathrm{Na}^{+}$$\mathrm{Ca}^{2+}$ exchanger [60], $\mathrm{Na}^{+}-\mathrm{Cl}^{-}$cotransporter (NCC) [58], NKCC [32], SGLT [59], glucose transporters [59], and urea transporters [61]. On the other hand, IFN- $\gamma$ seems to be involved in the upregulations of NKCC and NCC in the distal nephron and NHE in the proximal tubule, which would contribute to the salt and water retention during the angiotensin II-induced hypertension [34]. The stimulatory effect of IFN- $\gamma$ on $\mathrm{K}^{+}$channel activity might play a role in such an upregulated $\mathrm{Na}^{+}$transport. Similar to TNF- $\alpha$ and IFN- $\gamma$, the effects of IL1- $\beta$ on renal transporters are mainly suppressive, which is in good agreement with its suppressive effect on $\mathrm{K}^{+}$channel activity. IL- $1 \beta$ inhibits $\mathrm{Na}^{+}$reabsorption in the CCD [27] and expression of $\mathrm{Na}^{+}-\mathrm{K}^{+}$ATPase in medullary and cortical kidney cells [28] or cultured LLC$\mathrm{PK}_{1}$ cells [29]. It also reduces many other transporters, as was observed with IFN- $\gamma[32,58,59,61]$.

\section{Effects of Cytokines on $\mathrm{K}^{+}$Channel Activity and Renal Cell Injury}

The effects of proinflammatory cytokines on renal $\mathrm{K}^{+}$channels would be implicated in renal dysfunction or renal cell injury. Proinflammatory cytokines are the key molecules, which promote cell injury in many organs during inflammatory diseases $[9,10]$. They are involved in the pathogenesis of acute kidney injury and chronic kidney disease [62, 63]. The endotoxemia-induced acute renal failure is one of the clinical manifestations that highlight the detrimental effects of proinflammatory cytokines on the kidney [64]. Therapeutic use of cytokines sometimes brings about adverse effects. For example, application of IFNs in renal cell carcinoma or viral hepatitis may well result in undesirable severe renal dysfunction [65]. Furthermore, it has been reported that proinflammatory cytokines cause glomerulonephritis accompanied by proteinuria, tubulointerstitial fibrosis, and apoptosis/necrosis of tubular cells in various experimental models $[66,67]$. These effects are generally thought to be mediated by activation of caspases and various transcription factors $[9,10]$. The activated transcription factors initiate synthesis of many effector proteins, such as other cytokines, chemokines, matrix metalloproteases, iNOS, and adhesion molecules $[9,10]$. All of these effector proteins could participate in the promotion of renal cell injury. As described below, the changes in $\mathrm{K}^{+}$channel activity themselves could affect 
cell viability. Thus, it is possible that the cytokine-induced renal cell injury would be mediated by modulation of $\mathrm{K}^{+}$ channel activity. In fact, TGF- $\beta$ upregulates a $\mathrm{Ca}^{2+}$-activated $\mathrm{K}^{+}$channel in HK2 cells, which in turn contributed to the generation of a chemokine crucial for the pathogenesis of renal fibrosis [50]. Modulation of $\mathrm{K}^{+}$channel activity by TNF$\alpha$ was also reported to induce cell death in a rat liver cell line [68] and prolonged action potential duration, which was involved in the sudden cardiac death, in dog cardiomyocytes [69].

Many reports have demonstrated that changes in activity of renal tubular $\mathrm{K}^{+}$channels would be involved in renal cell injury. With regard to the mode of action of $\mathrm{K}^{+}$channel activity on renal cell injury, however, profound controversy exists. An ATP-sensitive $\mathrm{K}^{+}$channel $\left(\mathrm{K}_{\mathrm{ATP}}\right)$ blocker, glibenclamide, was reported to reduce hypoxia- or ischemia/reperfusioninduced renal cell injury in isolated rat proximal tubules [3], perfused rat kidneys [4], and rats in vivo [5]. Glibenclamide also improved kidney structure and function in the rat model of chronic kidney disease [70]. Blocking the activity of KCa3.1 $\mathrm{K}^{+}$channel by TRAM34 inhibited production of inflammatory mediators, which contributed to renal fibrosis, in HK2 cells [50, 71] or diabetic mice [72]. It was reported that the downregulation of Kir4.1 by intracellular acidification would contribute to cell protection in the rat proximal tubule [73]. These findings suggested that increased $\mathrm{K}^{+}$channel activity would cause renal cell injury. In contrast, other investigators reported that maintaining or increasing $\mathrm{K}^{+}$ channel activity is rather protective for renal cells. According to their reports, blockade of $\mathrm{K}^{+}$channel by glibenclamide enhanced renal cell injury in isolated perfused rat kidney [6], LLC-PK 1 cells [7], HK2 cells [8], and mouse proximal tubule cells [8]. Furthermore, a $\mathrm{K}_{\text {ATP }}$ opener, nicorandil, was reported to ameliorate ischemia/reperfusion injury in the rat kidney $[74,75]$. Another $\mathrm{K}_{\text {ATP }}$ opener, levosimendan, also protects the kidney against the LPS-induced inflammatory responses [8] and ischemia/reperfusion injury [76]. The discrepant effects of altered $\mathrm{K}^{+}$channel activity among reports would partly be due to the differences in experimental systems and cellular conditions. The precise mechanisms by which changes in $\mathrm{K}^{+}$channel activity cause renal cell injury are not completely revealed. It is likely that the loss of intracellular $\mathrm{K}^{+}$through the activated $\mathrm{K}^{+}$channel facilitates cell shrinkage, which triggers apoptotic volume decrease [77]. Furthermore, changes in $\mathrm{K}^{+}$channel activity alter the driving force for $\mathrm{Ca}^{2+}$ entry through $\mathrm{Ca}^{2+}$-permeable channels, such as TRP channels $[78,79]$. Subsequent changes in intracellular $\mathrm{Ca}^{2+}$ concentration will activate or suppress various factors, including apoptotic or inflammatory molecules $[50,71,72,78$, 79]. It also remained to be elucidated whether the cytotoxic effects of proinflammatory cytokines would actually be mediated by their modulation of renal $\mathrm{K}^{+}$channel activity.

\section{Conclusion}

Renal $\mathrm{K}^{+}$channels play important roles in maintaining the normal transport function of renal tubule epithelia. The kidney sometimes suffers from renal ischemia, endotoxemia, and diabetic nephropathy, where proinflammatory cytokines are produced. However, it was only during the last decade that the effects of proinflammatory cytokines on renal $\mathrm{K}^{+}$channels were reported. The effects of cytokines on $\mathrm{K}^{+}$channels may be involved in alterations of tubular transport or onset of renal cell injury. However, the physiological and pathological significances of proinflammatory cytokines in modulating renal tubular $\mathrm{K}^{+}$channels are not well understood. To complicate the matters, a variety of cytokines with different actions are produced during inflammatory responses. Some cytokines activate renal $\mathrm{K}^{+}$channels, while others suppress the same channels. The complexity of cytokine actions gives rise to difficulties in interpreting the final outcome of their effects. Additional studies are required to further clarify the effects of proinflammatory cytokines on renal $\mathrm{K}^{+}$channels.

\section{Conflict of Interests}

The authors declare that there is no conflict of interests regarding the publication of this paper.

\section{References}

[1] S. C. Hebert, G. Desir, G. Giebisch, and W. Wang, "Molecular diversity and regulation of renal potassium channels," Physiological Reviews, vol. 85, no. 1, pp. 319-371, 2005.

[2] G. H. Giebisch, "A long affair with renal tubules," Annual Review of Physiology, vol. 73, pp. 1-28, 2011.

[3] W. B. Reeves and S. V. Shah, "Activation of potassium channels contributes to hypoxic injury in proximal tubules," The Journal of Clinical Investigation, vol. 94, no. 6, pp. 2289-2294, 1994.

[4] R. Engbersen, M. M. Moons, A. C. Wouterse et al., "Sulphonylurea drugs reduce hypoxic damage in the isolated perfused rat kidney," British Journal of Pharmacology, vol. 130, no. 7, pp. 1678-1684, 2000.

[5] K. Pompermayer, D. G. Souza, G. G. Lara et al., "The ATPsensitive potassium channel blocker glibenclamide prevents renal ischemia/reperfusion injury in rats," Kidney International, vol. 67, no. 5, pp. 1785-1796, 2005.

[6] M. Rahgozar, D. A. Willgoss, G. C. Gobé, and Z. H. Endre, "ATPdependent $\mathrm{K}^{+}$channels in renal ischemia reperfusion injury," Renal Failure, vol. 25, no. 6, pp. 885-896, 2003.

[7] A. R. Assad, J. M. A. Delou, L. M. Fonseca et al., "The role of KATP channels on propofol preconditioning in a cellular model of renal ischemia-reperfusion," Anesthesia \& Analgesia, vol. 109, no. 5, pp. 1486-1492, 2009.

[8] R. A. Zager, A. C. Johnson, S. Lund, S. Y. Hanson, and C. K. Abrass, "Levosimendan protects against experimental endotoxemic acute renal failure," The American Journal of PhysiologyRenal Physiology, vol. 290, no. 6, pp. F1453-F1462, 2006.

[9] C. A. Feghali and T. M. Wright, "Cytokines in acute and chronic inflammation," Frontiers in Bioscience, vol. 2, pp. 12-26, 1997.

[10] C. A. Dinarello, "Historical insights into cytokines," European Journal of Immunology, vol. 37, supplement 1, pp. S34-S45, 2007.

[11] M. Schäfers and L. Sorkin, "Effect of cytokines on neuronal excitability," Neuroscience Letters, vol. 437, no. 3, pp. 188-193, 2008.

[12] S. M. Allan, P. J. Tyrrell, and N. J. Rothwell, "Interleukin-1 and neuronal injury," Nature Reviews Immunology, vol. 5, no. 8, pp. 629-640, 2005. 
[13] V. C. Mehra, V. S. Ramgolam, and J. R. Bender, "Cytokines and cardiovascular disease," Journal of Leukocyte Biology, vol. 78, no. 4, pp. 805-818, 2005.

[14] H. Kimura, M. Yoshizumi, H. Ishii, K. Oishi, and A. Ryo, "Cytokine production and signaling pathways in respiratory virus infection," Frontiers in Microbiology, vol. 4, article 276, 2013.

[15] H. Akiho, E. Ihara, Y. Motomura, and K. Nakamura, "Cytokineinduced alterations of gastrointestinal motility in gastrointestinal disorders," World Journal of Gastrointestinal Pathophysiology, vol. 2, no. 5, pp. 72-81, 2011.

[16] E. D. Morrell, J. A. Kellum, K. R. Hallows, and N. M. PastorSoler, "Epithelial transport during septic acute kidney injury," Nephrology Dialysis Transplantation, vol. 29, no. 7, pp. 1312-1319, 2014.

[17] R. A. Zager, A. C. M. Johnson, and A. Geballe, "Gentamicin suppresses endotoxin-driven TNF- $\alpha$ production in human and mouse proximal tubule cells," American Journal of PhysiologyRenal Physiology, vol. 293, no. 4, pp. F1373-F1380, 2007.

[18] G. K. Rangan, Y. Wang, Y.-C. Tay, and D. C. H. Harris, "Differential effects of albumin on cytokine gene expression in proximal tubular epithelial cells," Nephrology Dialysis Transplantation, vol. 20, no. 5, pp. 1013-1014, 2005.

[19] M. R. Daha and C. van Kooten, "Is the proximal tubular cell a proinflammatory cell?" Nephrology Dialysis Transplantation, vol. 15, supplement 6, pp. 41-43, 2000.

[20] N. Nakhoul and V. Batuman, "Role of proximal tubules in the pathogenesis of kidney disease," Contributions to Nephrology, vol. 169, pp. 37-50, 2011.

[21] B. A. Escalante, N. R. Ferreri, C. E. Dunn, and J. C. McGiff, "Cytokines affect ion transport in primary cultured thick ascending limb of Henle's loop cells," American Journal of Physiology, vol. 266, no. 6, pp. C1568-C1576, 1994.

[22] N. R. Ferreri, B. A. Escalante, Y. Zhao, S.-J. An, and J. C. McGiff, "Angiotensin II induces TNF production by the thick ascending limb: functional implications," American Journal of Physiology-Renal Physiology, vol. 274, no. 1, pp. F148-F155, 1998.

[23] I. Tikkanen, N. Uhlenius, T. Tikkanen et al., "Increased renal expression of cytokines and growth factors induced by DOCA$\mathrm{NaCl}$ treatment in Heymann nephritis," Nephrology Dialysis Transplantation, vol. 10, no. 12, pp. 2192-2198, 1995.

[24] J. S. Gerritsma, A. F. Gerritsen, M. De Ley, L. A. van Es, and M. R. Daha, "Interferon- $\gamma$ induces biosynthesis of complement components $\mathrm{C} 2, \mathrm{C} 4$ and factor $\mathrm{H}$ by human proximal tubular epithelial cells," Cytokine, vol. 9, no. 4, pp. 276-283, 1997.

[25] J. R. Timoshanko, A. R. Kitching, Y. Iwakura, S. R. Holdsworth, and P. G. Tipping, "Leukocyte-derived interleukin- $1 \beta$ interacts with renal interleukin-1 receptor I to promote renal tumor necrosis factor and glomerular injury in murine crescentic glomerulonephritis," The American Journal of Pathology, vol. 164, no. 6, pp. 1967-1977, 2004.

[26] A. Castillo, M. T. Islam, M. C. Prieto, and D. S. A. Majid, "Tumor necrosis factor- $\alpha$ receptor type 1 , not type 2 , mediates its acute responses in the kidney," American Journal of Physiology-Renal Physiology, vol. 302, no. 12, pp. F1650-F1657, 2012.

[27] Y. Sakairi, Y. Ando, K. Tabei, E. Kusano, and Y. Asano, "Interleukin-1 inhibits sodium and water transport in rabbit cortical collecting duct," American Journal of Physiology-Renal Fluid and Electrolyte Physiology, vol. 266, no. 4, pp. F674-F680, 1994.
[28] S. I. Kreydiyyeh and R. Al-Sadi, "Interleukin- $1 \beta$ increases urine flow rate and inhibits protein expression of $\mathrm{Na}^{+} / \mathrm{K}^{+}$-ATPase in the rat jejunum and kidney," Journal of Interferon \& Cytokine Research, vol. 22, no. 10, pp. 1041-1048, 2002.

[29] S. I. Kreydiyyeh and R. Al-Sadi, "The signal transduction pathway that mediates the effect of interleukin-1 beta on the $\mathrm{Na}^{+}-\mathrm{K}^{+}$-ATPase in LLC-PK 1 cells," Pflügers Archiv, vol. 448, no. 2, pp. 231-238, 2004.

[30] M. Vinciguerra, U. Hasler, D. Mordasini et al., "Cytokines and sodium induce protein kinase A-dependent cell-surface $\mathrm{Na}$, K-ATPase recruitment via dissociation of NF- $\kappa \mathrm{B} / \mathrm{I} \kappa \mathrm{B} /$ protein kinase A catalytic subunit complex in collecting duct principal cells," Journal of the American Society of Nephrology, vol. 16, no. 9, pp. 2576-2585, 2005.

[31] S. I. Kreydiyyeh and S. Markossian, "Tumor necrosis factor $\alpha$ down-regulates the $\mathrm{Na}^{+}-\mathrm{K}^{+}$ATPase and the $\mathrm{Na}^{+}-\mathrm{K}^{+} 2 \mathrm{Cl}^{-}$ cotransporter in the kidney cortex and medulla," Cytokine, vol. 33, no. 3, pp. 138-144, 2006.

[32] C. Schmidt, K. Höcherl, F. Schweda, A. Kurtz, and M. Bucher, "Regulation of renal sodium transporters during severe inflammation," Journal of the American Society of Nephrology, vol. 18, no. 4, pp. 1072-1083, 2007.

[33] S. Battula, S. Hao, P. L. Pedraza, C. T. Stier, and N. R. Ferreri, "Tumor necrosis factor- $\alpha$ is an endogenous inhibitor of $\mathrm{Na}^{+}$$\mathrm{K}^{+}-2 \mathrm{Cl}^{-}$cotransporter (NKCC2) isoform a in the thick ascending limb," American Journal of Physiology-Renal Physiology, vol. 301, no. 1, pp. F94-F100, 2011.

[34] N. V. Kamat, S. R. Thabet, L. Xiao et al., "Renal transporter activation during angiotensin-II hypertension is blunted in interferon- $\gamma^{-/-}$and interleukin-17 $\mathrm{A}^{-/-}$mice," Hypertension, vol. 65, no. 3, pp. 569-576, 2015.

[35] B. Viviani, F. Gardoni, and M. Marinovich, "Cytokines and neuronal ion channels in health and disease," International Review of Neurobiology, vol. 82, pp. 247-263, 2007.

[36] K. Nakamura, Y. Komagiri, T. Kojo, and M. Kubokawa, "Effects of cytokines on activity of an inwardly rectifying $\mathrm{K}^{+}$channel in cultured human proximal tubule cells," The Journal of the Iwate Medical Association, vol. 59, no. 5, pp. 375-385, 2007.

[37] K. Nakamura, Y. Komagiri, T. Kojo, and M. Kubokawa, "Delayed and acute effects of interferon- $\gamma$ on activity of an inwardly rectifying $\mathrm{K}^{+}$channel in cultured human proximal tubule cells," American Journal of Physiology-Renal Physiology, vol. 296, no. 1, pp. F46-F53, 2009.

[38] K. Nakamura, Y. Komagiri, and M. Kubokawa, "Interleukin$1 \beta$ suppresses activity of an inwardly rectifying $\mathrm{K}^{+}$channel in human renal proximal tubule cells," Journal of Physiological Sciences, vol. 63, no. 5, pp. 377-387, 2013.

[39] K. Nakamura, J. Hirano, and M. Kubokawa, "An ATP-regulated and $\mathrm{pH}$-sensitive inwardly rectifying $\mathrm{K}^{+}$channel in cultured human proximal tubule cells," Japanese Journal of Physiology, vol. 51, no. 4, pp. 523-530, 2001.

[40] K. Nakamura, J. Hirano, and M. Kubokawa, "Regulation of an inwardly rectifying $\mathrm{K}^{+}$channel by nitric oxide in cultured human proximal tubule cells," American Journal of PhysiologyRenal Physiology, vol. 287, no. 3, pp. F411-F417, 2004.

[41] M. Kubokawa, T. Kojo, Y. Komagiri, and K. Nakamura, "Role of calcineurin-mediated dephosphorylation in modulation of an inwardly rectifying $\mathrm{K}^{+}$channel in human proximal tubule cells," Journal of Membrane Biology, vol. 231, no. 2-3, pp. 79-92, 2009.

[42] K. L. Hamilton and D. C. Devor, "Basolateral membrane $\mathrm{K}^{+}$channels in renal epithelial cells," American Journal of 
Physiology-Renal Physiology, vol. 302, no. 9, pp. F1069-F1081, 2012.

[43] K. Nakamura, J. Hirano, S.-I. Itazawa, and M. Kubokawa, "Protein kinase $\mathrm{G}$ activates inwardly rectifying $\mathrm{K}^{+}$channel in cultured human proximal tubule cells," American Journal of Physiology-Renal Physiology, vol. 283, no. 4, pp. F784-F791, 2002.

[44] L. C. Platanias, "Mechanisms of type-I- and type-II-interferonmediated signalling," Nature Reviews Immunology, vol. 5, no. 5, pp. 375-386, 2005.

[45] P. Lipp and G. Reither, "Protein kinase C: the 'masters' of calcium and lipid," Cold Spring Harbor Perspectives in Biology, vol. 3, no. 7, Article ID a004556, 2011.

[46] C. R. Plata-Salamán and J. M. H. Ffrench-Mullen, "Interleukin$1 \beta$ inhibits $\mathrm{Ca}^{2+}$ channel currents in hippocampal neurons through protein kinase C," European Journal of Pharmacology: Molecular Pharmacology, vol. 266, no. 1, pp. 1-10, 1994.

[47] J. Y. Choi, Y.-S. Choi, S. J. Kim, E. J. Son, H. S. Choi, and J.H. Yoon, "Interleukin- $1 \beta$ suppresses epithelial sodium channel $\beta$-subunit expression and ENaC-dependent fluid absorption in human middle ear epithelial cells," European Journal of Pharmacology, vol. 567, no. 1-2, pp. 19-25, 2007.

[48] E. G. Cafferata, A. M. González-Guerrico, L. Giordano, O. H. Pivetta, and T. A. Santa-Coloma, "Interleukin- $1 \beta$ regulates CFTR expression in human intestinal T84 cells," Biochimica et Biophysica Acta, vol. 1500, no. 2, pp. 241-248, 2000.

[49] P. K. Chatterjee, G. M. Hawksworth, and J. S. McLay, "Cytokinestimulated nitric oxide production in the human renal proximal tubule and its modulation by natriuretic peptides: a novel immunomodulatory mechanism?" Experimental Nephrology, vol. 7, no. 5-6, pp. 438-448, 1999.

[50] C. Huang, M. L. Day, P. Poronnik, C. A. Pollock, and X.-M. Chen, "Inhibition of KCa3.1 suppresses TGF- $\beta 1$ induced MCP1 expression in human proximal tubular cells through Smad3, p38 and ERK1/2 signaling pathways," The International Journal of Biochemistry \& Cell Biology, vol. 47, no. 1, pp. 1-10, 2014.

[51] H. Wulff and N. A. Castle, "Therapeutic potential of $\mathrm{K}_{\mathrm{Ca}} 3.1$ blockers: recent advances and promising trends," Expert Review of Clinical Pharmacology, vol. 3, no. 3, pp. 385-396, 2010.

[52] Y. Wei, E. Babilonia, P. L. Pedraza, N. R. Ferreri, and W.-H. Wang, "Acute application of TNF stimulates apical 70-pS $\mathrm{K}^{+}$ channels in the thick ascending limb of rat kidney," American Journal of Physiology-Renal Physiology, vol. 285, no. 3, pp. F491-F497, 2003.

[53] D. Li, Y. Wei, and W.-H. Wang, "Dietary K intake regulates the response of apical $\mathrm{K}$ channels to adenosine in the thick ascending limb," American Journal of Physiology-Renal Physiology, vol. 287, no. 5, pp. F954-F959, 2004.

[54] M. Lu, X. Wang, and W. Wang, "Nitric oxide increases the activity of the apical 70-pS $\mathrm{K}^{+}$channel in TAL of rat kidney," American Journal of Physiology-Renal Physiology, vol. 274, no. 5, pp. F946-F950, 1998.

[55] D. Wang, P. L. Pedraza, H. I. Abdullah, J. C. McGiff, and N. R. Ferreri, "Calcium-sensing receptor-mediated TNF production in medullary thick ascending limb cells," American Journal of Physiology-Renal Physiology, vol. 283, no. 5, pp. F963-F970, 2002.

[56] H. J. Liu, Y. Wei, N. R. Fererri, A. Nasjletti, and W. H. Wang, "Vasopressin and PGE2 regulate activity of apical $70 \mathrm{pS} \mathrm{\textrm {K } ^ { + }}$ channel in thick ascending limb of rat kidney," American Journal of Physiology-Cell Physiology, vol. 278, no. 5, pp. C905-C913, 2000 .
[57] M. I. Maldonado-Cervantes, O. G. Galicia, B. Moreno-Jaime et al., "Autocrine modulation of glucose transporter SGLT2 by IL- 6 and TNF- $\alpha$ in LLC-PK 1 cells," Journal of Physiology and Biochemistry, vol. 68, no. 3, pp. 411-420, 2012.

[58] C. Schmidt, K. Höcherl, F. Schweda, and M. Bucher, "Proinflammatory cytokines cause down-regulation of renal chloride entry pathways during sepsis," Critical Care Medicine, vol. 35, no. 9, pp. 2110-2119, 2007.

[59] C. Schmidt, K. Höcherl, and M. Bucher, "Regulation of renal glucose transporters during severe inflammation," American Journal of Physiology-Renal Physiology, vol. 292, no. 2, pp. F804-F811, 2007.

[60] V. M. Radhakrishnan, P. Kojs, R. Ramalingam et al., "Experimental colitis is associated with transcriptional inhibition of $\mathrm{Na}^{+} / \mathrm{Ca}^{2+}$ exchanger isoform 1 (NCX1) expression by interferon $\gamma$ in the renal distal convoluted tubules," The Journal of Biological Chemistry, vol. 290, no. 14, pp. 8964-8974, 2015.

[61] C. Schmidt, K. Höcherl, and M. Bucher, "Cytokine-mediated regulation of urea transporters during experimental endotoxemia," American Journal of Physiology-Renal Physiology, vol. 292, no. 5, pp. F1479-F1489, 2007.

[62] G. Ramesh and W. B. Reeves, "Inflammatory cytokines in acute renal failure," Kidney International, Supplement, vol. 66, no. 91, pp. S56-S61, 2004.

[63] L. M. Ortega and A. Fornoni, "Role of cytokines in the pathogenesis of acute and chronic kidney disease, glomerulonephritis, and end-stage kidney disease," International Journal of Interferon, Cytokine and Mediator Research, vol. 2, no. 1, pp. 49-62, 2010.

[64] R. W. Schrier and W. Wang, "Acute renal failure and sepsis," The New England journal of medicine, vol. 351, no. 2, pp. 159-169, 2004.

[65] E. Jonasch and F. G. Haluska, "Interferon in oncological practice: review of interferon biology, clinical applications, and toxicities," Oncologist, vol. 6, no. 1, pp. 34-55, 2001.

[66] T. M. Phillips, "Interferon-alpha induces renal dysfunction and injury," Current Opinion in Nephrology and Hypertension, vol. 5, no. 4, pp. 380-383, 1996.

[67] D. A. Vesey, C. Cheung, Z. Endre, G. Gobé, and D. W. Johnson, "Role of protein kinase $C$ and oxidative stress in interleukin- $1 \beta$ induced human proximal tubule cell injury and fibrogenesis," Nephrology, vol. 10, no. 1, pp. 73-80, 2005.

[68] H. H. Nietsch, M. W. Roe, J. F. Fiekers, A. L. Moore, and S. D. Lidofsky, "Activation of potassium and chloride channels by tumor necrosis factor $\alpha$. Role in liver cell death," The Journal of Biological Chemistry, vol. 275, no. 27, pp. 20556-20561, 2000.

[69] J. Wang, H. Wang, Y. Zhang, H. Gao, S. Nattel, and Z. Wang, "Impairment of HERG $\mathrm{K}^{+}$channel function by tumor necrosis factor- $\alpha$ : role of reactive oxygen species as a mediator," The Journal of Biological Chemistry, vol. 279, no. 14, pp. 13289-13292, 2004.

[70] V. Diwan, G. Gobe, and L. Brown, "Glibenclamide improves kidney and heart structure and function in the adenine-diet model of chronic kidney disease," Pharmacological Research, vol. 79, pp. 104-110, 2014.

[71] C. Huang, C. A. Pollock, and X.-M. Chen, "High glucose induces CCL20 in proximal tubular cells via activation of the KCa3.1 channel," PLoS ONE, vol. 9, no. 4, Article ID e95173, 2014.

[72] C. Huang, S. Shen, Q. Ma et al., "Blockade of KCa3.1 ameliorates renal fibrosis through the TGF- $\beta 1 /$ smad pathway in diabetic mice," Diabetes, vol. 62, no. 8, pp. 2923-2934, 2013. 
[73] M. A. Garcia, R. Meca, D. Leite, and M. A. Boim, "Effect of renal ischemia/reperfusion on gene expression of a $\mathrm{pH}$-sensitive $\mathrm{K}^{+}$ channel," Nephron Physiology, vol. 106, no. 1, pp. 1-7, 2007.

[74] S. Shimizu, M. Saito, Y. Kinoshita et al., "Nicorandil ameliorates ischaemia-reperfusion injury in the rat kidney," British Journal of Pharmacology, vol. 163, no. 2, pp. 272-282, 2011.

[75] Y.-J. Zhang, A.-Q. Zhang, X.-X. Zhao, Z.-L. Tian, and L. Yao, "Nicorandil protects against ischaemia-reperfusion injury in newborn rat kidney," Pharmacology, vol. 92, no. 5-6, pp. 245256, 2014.

[76] E. Grossini, C. Molinari, P. Pollesello et al., "Levosimendan protection against kidney ischemia/reperfusion injuries in anesthetized pigs," Journal of Pharmacology and Experimental Therapeutics, vol. 342, no. 2, pp. 376-388, 2012.

[77] L. C. Penning, G. Denecker, D. Vercammen, W. Declercq, R. G. Schipper, and P. Vandenabeele, "A role for potassium in TNFinduced apoptosis and gene-induction in human and rodent tumour cell lines," Cytokine, vol. 12, no. 6, pp. 747-750, 2000.

[78] F. Lang, E. Shumilina, M. Ritter, E. Gulbins, A. Vereninov, and S. M. Huber, "Ion channels and cell volume in regulation of cell proliferation and apoptotic cell death," Contributions to Nephrology, vol. 152, pp. 142-160, 2006.

[79] G. Shapovalov, V. Lehen'kyi, R. Skryma, and N. Prevarskaya, "TRP channels in cell survival and cell death in normal and transformed cells," Cell Calcium, vol. 50, no. 3, pp. 295-302, 2011. 


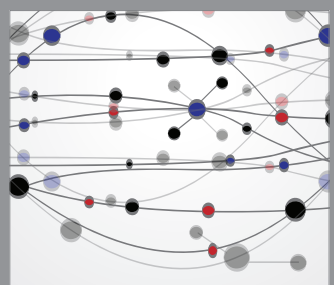

The Scientific World Journal
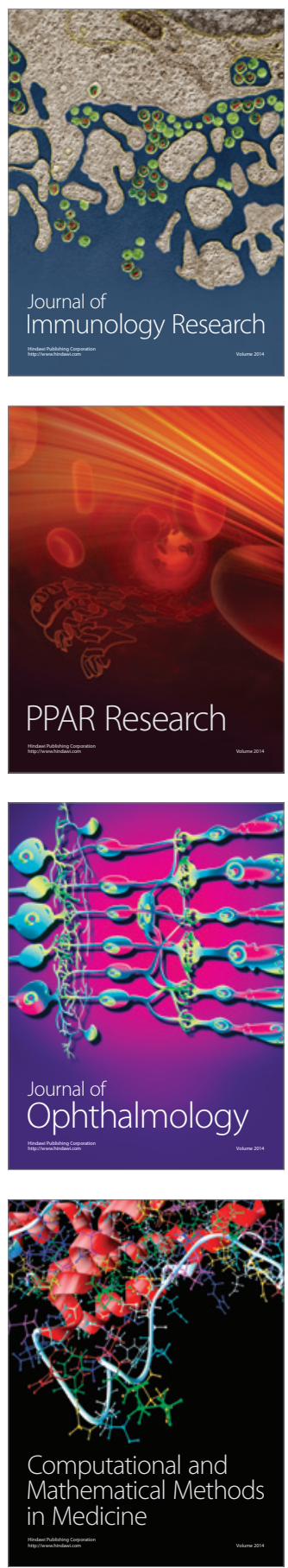

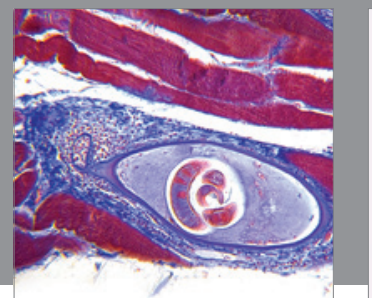

Gastroenterology

Research and Practice
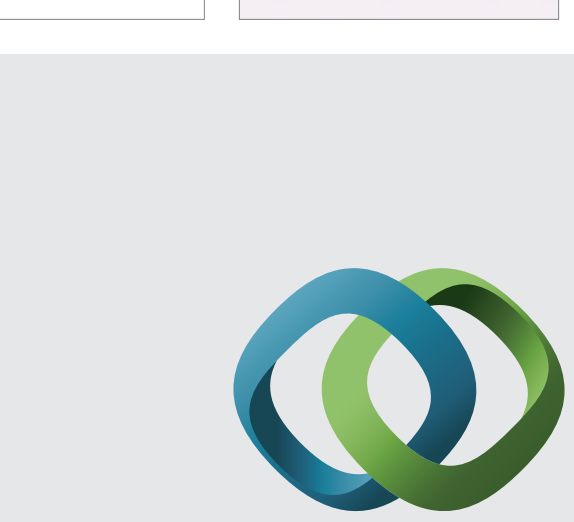

\section{Hindawi}

Submit your manuscripts at

http://www.hindawi.com
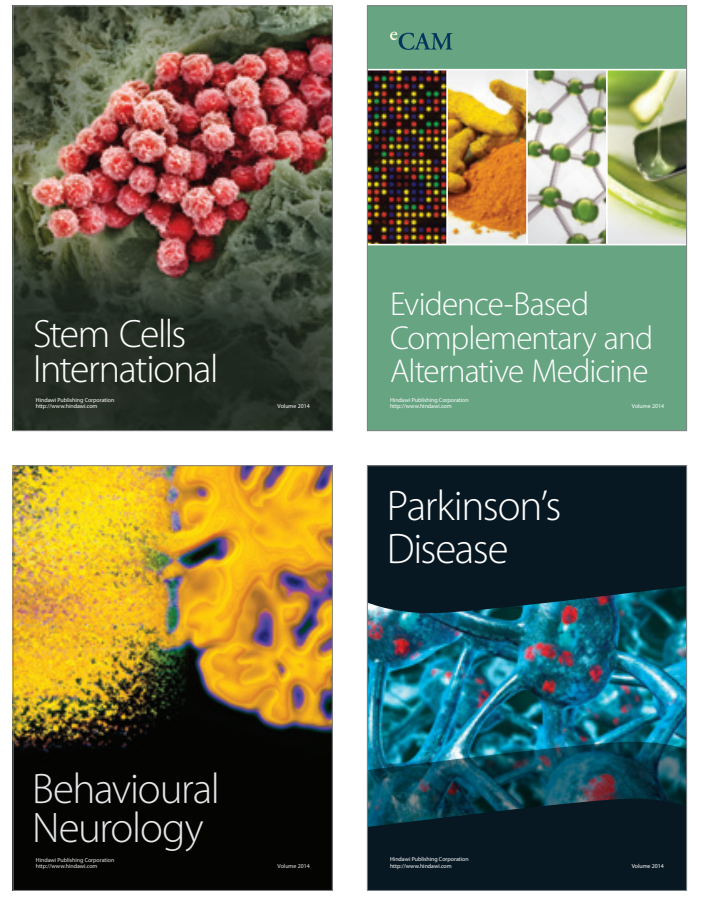
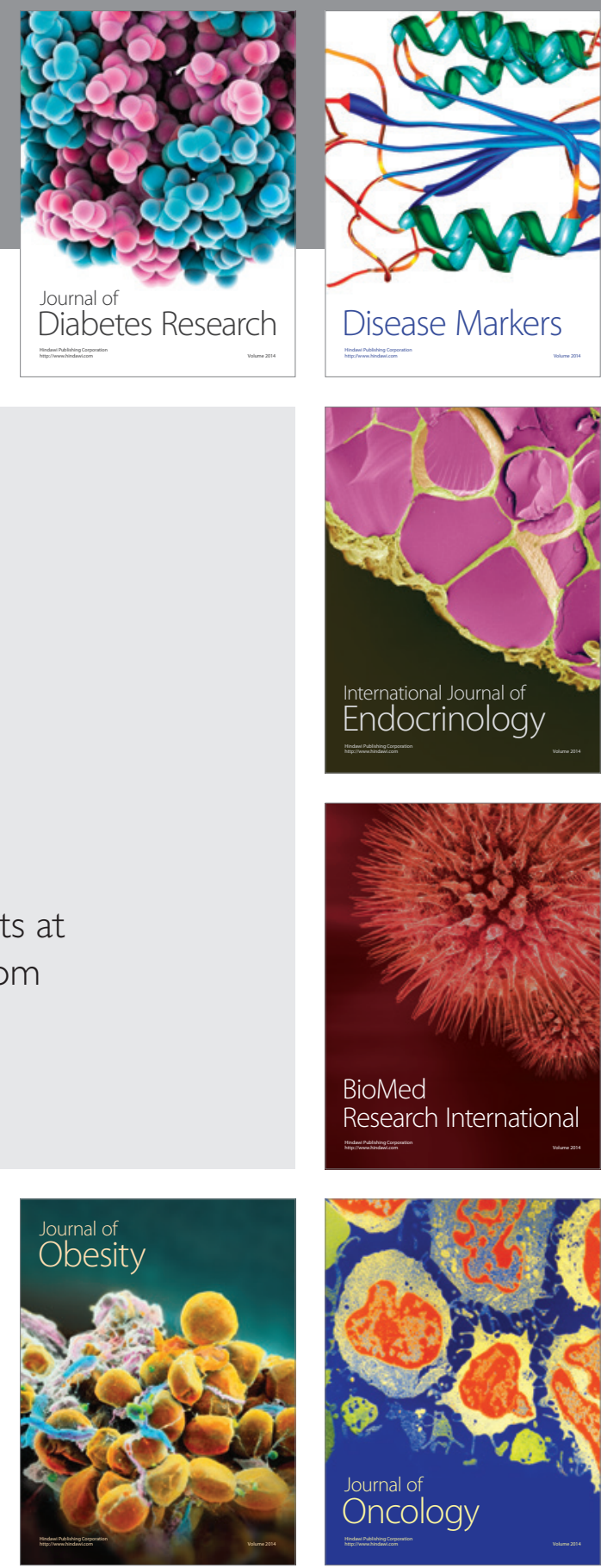

Disease Markers
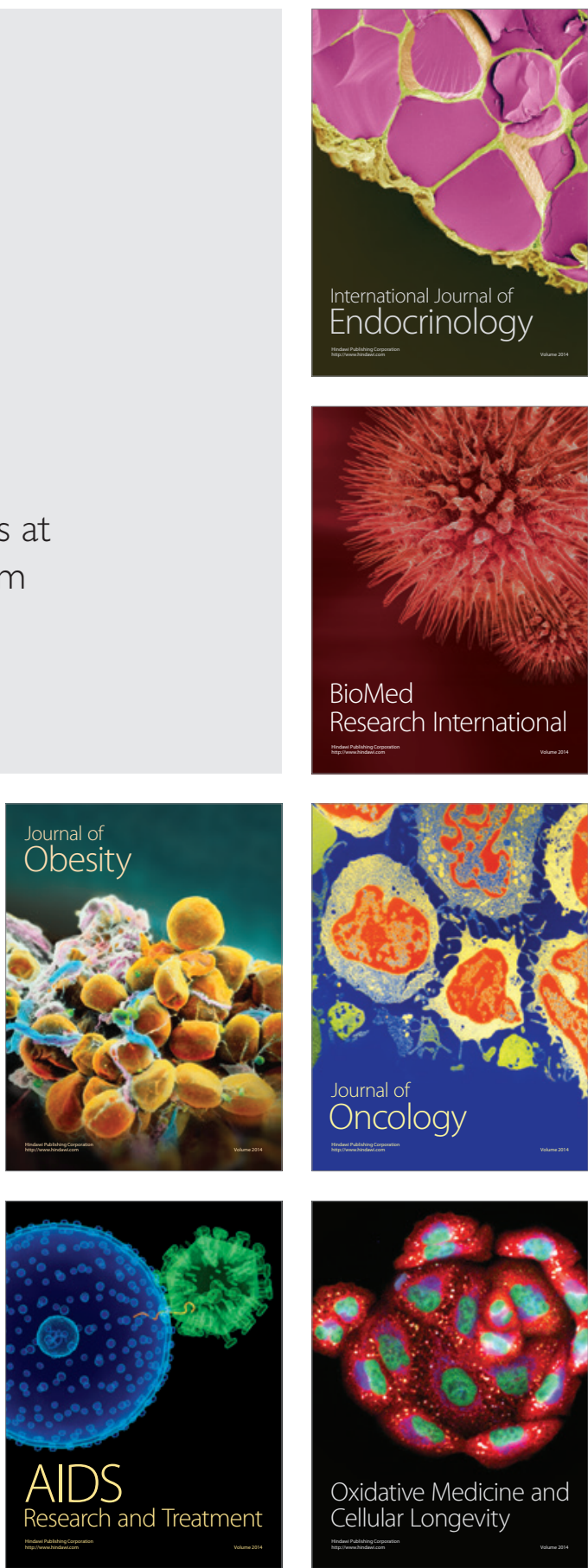